\title{
Effect of hospital mobile website quality and service scape $p$ erceived by medical tourists on hospital image and revisit in tention - focusing on Chinese medical tourists
}

\author{
Seon-Hee Ko, Department of Airline Service, Faculty of Human Service, Seo-Won University, Chung-Buk, \\ 28674, Korea, sunny_ko@hanmail.net \\ ${ }^{*}$ Corresponding Author
}

\begin{abstract}
This study intends to analyze the effect of hospital mobile website quality, service scape on hospital image and revisit intention using Chinese medical tourists. This research conducted a survey to Chinese medical tourists from January 17 to 22, 2019. By distributing 150 copies of the questionnaire to them in cosmetic surgery and dermatology clinics in Seoul, and collected 147 of them. Excluding 20 copies that had missing values, this research used 127 copies for final analysis. Collected data were analyzed using statistical programs like SPSS 21.0, and AMOS 22.0. The conclusion about the findings and suggestions are as follows. First, among the kinds of hospital website quality, information quality (H1-1) and system design quality (H1-3) have significant positive effects on hospital image. That is, the more tourists positively perceive information on the hospital, on the medical team of the hospital, on surgery process, and on the effects of surgery, the higher their image of the hospital gets. And the more they perceive the type style, colors, layout, and buttons of the website as convenient and useful, the higher their image of the hospital gets. Meanwhile, among the kinds of mobile website quality, reservation and tourism service were found not to affect hospital image. Second, H2 was partially adopted. Among ambient factor, design factor, and social factor of hospital service scape, design factor and social factor were found to significantly affect hospital image. Third, it was found that hospital image has positive effect on revisit intention, and willingness to encourage the hospital to others among medical tourists.
\end{abstract}

Keywords: Medical Tourism, Medical Tourist, Hospital Mobile Website Quality, Hospital Image, Revisit Intention

Received: 08.12.2020 Accepted: 10.01.2021 Published: 02.02.2021

\section{INTRODUCTION}

Tourism is witnessing a continuous increase. The industry has surpassed the growth of the economy worldwide (World Travel and Tourism Council, 2017). Based on this, tourism sector has become one of the important and crucial industries to study and explore[1]. Medical tourism is the industry providing the patients who want to get medical treatment in foreign countries with related service, and, as it is linked to tourism and leisure-related service provided to patients while traveling to foreign countries, two concepts, 'medical treatment' and 'tourism' are combined. While the items included in medical tourism have been growing, major items currently considered as medical tourism are specialist treatment (various kinds of surgery and chemotherapy), elective procedures (plastic surgery and others), dental treatment, health check-up, spa, and related services[2].

Recently, as Korea has proved to have potential as attractive destinations of medical tourism, the central government and local governments have been very active in developing medical tourism linking it with local tourist attractions. Korean medical centers have price competitiveness, because, while they possess world-class facilities and cutting edge medical technologies, the prices imposed to patients are only 20-30\% of those in America[3].

Medical tourists search for information on the countries and hospitals as destinations of medical tourism through various channels. With the development of Internet and other media, they can search for such information through PC or mobile devices any time any place. With such a change of IT environment, information supply channels of hospitals have also become diverse. Hospitals information is available to anyone if he or she has PC or mobile devices. Digitalization is considered as the veritable vehicle of transformation for the tourism industry marketing in this age of the internet economy[4] Accordingly, in marketing strategies of hospitals, it is necessary to search for diverse and unique ways to provide information using mobile devices.

In selecting a medical center, medical tourist considers various elements such as the city it is located in, its appropriateness as medical facility, travel time, waiting time, and expenses, etc. Since medical tourist 
searches for various kinds of information about the medical center to know whether it fits his or her requirements, the medical center should go beyond providing simple information. And be aware that it can be the first step to communicate with the potential customer, and try to give a platform on which the medical center can build initial trust with the potential customer[5].

Website quality is evaluation and judgement of customers on the degree of excellence in providing Internet service[6], and quality customers generally perceive[7]. Hospital mobile website is "web environmental service of the hospital customers can access by smartphone through wireless Internet." The website works as catalyst to acquire information regarding medical service conveniently and quickly. In a study[8], comparing Korean and Chinese hospital websites classified them into several areas such as introduction of hospital, treatment, reservation service, customer service, and other information.

The study proving the importance of e-service quality in consumer's decision-making process, Among various characteristics of websites, particularly, the website system and design are important elements for customers to evaluate service quality, and screen expression, design, and type style are core elements for customers to judge quality of websites[5]. This study defines quality of hospital mobile website as "general feeling and evaluation of consumers on various contents, service, and the system provided by hospital mobile web." This study divides quality of hospital mobile website into three sub-factors: information, service, system and design. Considering the characteristics of medical tourists, composed each factor as follows: information consists of information on hospital, on medical teams, and on treatment; service consists of reservation service, tourism service, and other service; system and design consists of web system, style of type and color, layout and button.

As most websites contain medical information common people cannot easily understand, website quality must be considered as important to consumers. Website plays a great role as means of communication facilitating active communication with patients. In general, it is widely known that service quality is highly related with company image[9], and many researches have shown that service quality contributes to forming positive image of a company[10]. Consequently, we can expect that mobile website quality will improve hospital image. Several healthcare related studies [20-36] also considered.

Meanwhile, when medical tourists in foreign countries select Korea as their destination, they may well consider various factors. With the increase of the number of medical tourism suppliers, competition among medical centers have got tougher, and demands of potential patients have influenced medical centers to be bigger, more specialized, and become higher in facility quality. In particular, what new customers of a medical center visually check first is the facilities of the medical center, that is, physical environment of it. The term, service scape was first adopted by [11]. [11] called physical environment in the service industry 'service scape', which is artificial environment in contrast to natural, social environments. [11] divided service scape into three factors: ambient condition which is the pure condition of service facilities excluding social effects offered by [12]; spatial layout and functionality; sign, symbol \& artifacts. Service scape is all the physical elements customers can directly perceive at the place where service takes place.

In general, service scape is divided into three factors: ambient factors, design factors, and social factors[12-14]. Ambient factors are background elements that the customer does not immediately recognize and generally include lighting, temperature, acoustics, aroma, cleanliness etc. Design factors are architectural styles that customers can perceive compared to ambient factors, such as layout, comfort, and privacy, etc. And, social factors are personal factors like customers and employees in physical environment, specifically, the numbers of customers and employees, clothes of employees, degree of congestion, appearances behavior, and accessibility of employees[12].

In the current medical tourism markets across the world, technological gaps in medical service are not very great. In particular, it is very difficult for medical tourists to evaluate quality and level of medical tourism service in the technological aspect, except for checking the contents and results medical service providers give, Thus it is very important for customer satisfaction to provide customers with external clues like physical environment and making them have psychological comfort and trust to hospitals. In other words, if a hospital provides customers with a good service scape, it can induce favorable response and attitude of customers. By giving various sensual stimulants to customers by service scape, a hospital can build a good image about its service organization[15].

[12] suggesting that ambient condition is the precedent variable affecting customer's evaluation of service quality, argued that in particular design factors are directly related with perception and evaluation of customers on service quality. [11] argued that, when consumers evaluate physical environment of service, they consider ambient conditions, design, and social environment, and such factors provide reliable information to value perception of customers.

According to [16] who examined the relationship between service scape and service encounter in restaurant, discount store, and American football ground, service scape perception has positive effect on 
service quality and satisfaction; service quality perception on attitude, satisfaction, and service encounter results; satisfaction with service provider on attitude and service encounter results; attitude on service encounter results. In addition, [17] found that behavior in the service delivery process based on behavior of employees in physical environment, image factors, aroma and cleanliness in ambient condition affect customer orientation and trust, and such image ability becomes attractiveness, and responds in tangible joy in procurement decision-making process and mutual communication. Accordingly, based on the above discussions, this study set the following hypotheses on the relations among hospital website quality, service scape, hospital image, and satisfaction.

H1: Hospital mobile website quality will have positive effect on hospital image.

H2: Service scape will have positive effect on hospital image.

H3: Hospital image will have positive effect on satisfaction of medical tourists.

This study intends to empirically analyze the effect of hospital mobile website quality, service scape on hospital image and revisit intention who takes up the largest proportion of medical tourists visiting Korea. Through the analysis, this study wants to suggest the basis of the importance of mobile website quality and service scape, and extract the clues on the need to attract, secure medical tourists, and raise the revisit proportions through efficient management and improvement of mobile website quality and service scape.

\section{Materials and methods}

\subsection{Materials and Methods}

To fulfill the research aim, this research conducted a survey to Chinese medical tourists from January 17 to 22,2019 . By distributing 150 copies of the questionnaire to them in cosmetic surgery and dermatology clinics in Seoul, and collected 147 of them. Excluding 20 copies that had missing values, this research used 127 copies for final analysis. Collected data were analyzed using statistical programs like SPSS 21.0, and AMOS 22.0. To examine demographic characteristics of respondents, this research did frequency analysis, and, to test reliability of the data, it did confirmatory factor analysis and reliability test. In addition, to test effects among variables, it did structural equation model analysis.

\section{Results}

\subsection{General Characteristics}

Demographic characteristics of respondents are shown in Table 1. In gender distribution, the ration of females (89.9\%) was larger than males (11.1\%). In age distribution, the ratio of those in their 30s (30 39 years old) was the largest (44.9\%), followed by that of those in their 20s $(29.1 \%)$, that of those in their $40 \mathrm{~s}(23.6 \%)$, and that of those in their $50 \mathrm{~s}$ or over $(2.4 \%)$. Those under 40 years old took up the overwhelming majority $(74 \%)$. In educational levels, the largest ratio of them was college students or college graduates $(55.1 \%)$, followed by technical college students or graduates $(25.2 \%)$ and graduate school students or graduates (19.7\%). In the number of having visited Korea during the past one year, the largest proportion has visited Korea once (47.3\%), followed by twice (30.7\%), more than 4 times $(16.5 \%)$, and 3 times (5.5\%). In purposes of visiting Korea, most of them pointed out medical tourism (89.7\%) followed by visit to friend/ relative (5.5\%), business (2.4\%), and tourism/leisure $(2.4 \%)$. About the methods of searching for information on medical tourism, the largest proportion of them (93.7\%) directly accessed mobile websites of individual hospital or clinic, followed by checking through the portal site of Korea (6.3\%), and through the portal site on medical information. In the kinds of medical service they sought, the largest proportion was plastic surgery and beauty $(72.2 \%)$, followed by medical check-up (24.1\%), and other (3.7\%).

Table1 General Characteristics

\begin{tabular}{l|l|l|l}
\hline \multicolumn{2}{l|}{ Distinction } & Frequency & Percentage \\
\hline \multirow{3}{*}{ Gender } & Female & 113 & 88.9 \\
\cline { 2 - 4 } & Male & 14 & 11.1 \\
\hline \multirow{4}{*}{ Age } & $20-29$ & 37 & 29.1 \\
\cline { 2 - 4 } & $30-39$ & 57 & 44.9 \\
\cline { 2 - 4 } & $40-49$ & 30 & 23.6 \\
\cline { 2 - 4 } & 50 and above & 3 & 2.4 \\
\hline
\end{tabular}




\begin{tabular}{|c|c|c|c|}
\hline \multirow{3}{*}{ Education } & 2-year college graduates & 32 & 25.2 \\
\hline & Undergraduates & 70 & 55.1 \\
\hline & Graduates & 25 & 19.7 \\
\hline \multirow{4}{*}{$\begin{array}{l}\text { Visiting Korea } \\
\text { Per one year }\end{array}$} & once & 60 & 47.3 \\
\hline & twice & 39 & 30.7 \\
\hline & Three times & 7 & 5.5 \\
\hline & Over four times & 21 & 16.5 \\
\hline \multirow{2}{*}{$\begin{array}{l}\text { Method of } \\
\text { searching } \\
\text { hospital }\end{array}$} & Mobile websites of individual & 119 & 93.7 \\
\hline & Portal site of Korea & 8 & 6.3 \\
\hline \multirow{4}{*}{$\begin{array}{l}\text { Purpose of } \\
\text { Tourism }\end{array}$} & Medical Tour & 114 & 89.7 \\
\hline & Relative visit & 7 & 5.5 \\
\hline & Business & 3 & 2.4 \\
\hline & Tourism/leisure & 3 & 2.4 \\
\hline \multicolumn{2}{|l|}{ Total } & 127 & 100 \\
\hline
\end{tabular}

\subsection{Test of reliability and validity of measurement tools}

As the variables and items used in the model of this study were derived from previous researches, this study did confirmatory factor analysis to identify whether there is proper relationship between latent variables and measurement variables as shown in Table 2. To test goodness-of-fit of the model this study used $\chi 2$, CMIN/DF, RMR, RMSEA, GFI, AGFI, NFI and CFI values. And, to create high goodness-of-fit of the model, this study went through variable purifying process of eliminating questions whose SMC (squared multiple correlation) values were 400 or lower[18].

SMC value is the indicator used to judge whether measurement variable properly explains latent variable. Therefore, to improve goodness-of-fit of the model, this study eliminated IQ4 and SQ3 whose SMC values were lower than .400. After variable purifying process, the goodness-of-fit of the model became $\chi 2=372.699, \mathrm{df}=179, \mathrm{p}=.000, \mathrm{CMIN} / \mathrm{DF}=2.082, \mathrm{GFI}=.900, \mathrm{AGFI}=.875, \mathrm{NFI}=.905$ and $\mathrm{CFI}=.904$ as shown in Table 2. The criteria of the model fitness to test goodness-of-fit of structural equation model are GFI, AGFI $=.800$ or over, NFI, CFI $=.900$ or over, RMR $=.050$ or below, and RMSEA $=.100$ or below[18]. Accordingly, the goodness-of-fit of the measurement model of this study is acceptable. In addition, SMC values are all above .400 , explaining related latent variables.

After making confirmatory factor analysis of the measurement model, this study tested its validity. Construct reliability (CR) values was used as the indicator to evaluate convergent validity. Average variance extracted (AVE) was used as the indicator to evaluate discriminant validity. In test of convergent validity using CR value, if CR value is .879 or over, it is interpreted as having convergent validity. In test of discriminant validity using AVE value, if squared value of correlation coefficient is lower than AVE value, it is interpreted as securing discriminant validity [19]. Table 3 shows the analysis of discriminant validity.

Table2 Confirmatory factor analysis for the measurement model

\begin{tabular}{l|l|l|l|l|l}
\hline \multirow{2}{*}{ Factor } & $\begin{array}{l}\text { Measurement } \\
\text { Category }\end{array}$ & $\begin{array}{l}\text { Std. } \\
\text { factor } \\
\text { loading }\end{array}$ & t Value & SMC & AVE \\
\hline \multirow{3}{*}{$\begin{array}{l}\text { Information } \\
\text { Quality }\end{array}$} & IQ 1 & .877 & --- & .779 & \\
\cline { 2 - 5 } & IQ 2 & .817 & $13.128^{* *}$ & .780 & \multirow{2}{*}{.557} \\
\cline { 2 - 5 } & IQ 3 & .816 & $12.477^{* *}$ & .784 & \\
\hline Service & SQ1 & .713 & --- & .709 & .687 \\
\hline
\end{tabular}




\begin{tabular}{|c|c|c|c|c|c|}
\hline \multirow[t]{2}{*}{ Quality } & SQ 2 & .819 & $11.798^{* *}$ & .781 & \\
\hline & SQ 4 & .799 & $17.728^{* *}$ & .682 & \\
\hline \multirow{3}{*}{$\begin{array}{l}\text { System and Design } \\
\text { Quality }\end{array}$} & SDQ 1 & .779 & --- & .668 & \multirow{3}{*}{.590} \\
\hline & SDQ 2 & .834 & $13.114^{* *}$ & .680 & \\
\hline & SDQ 3 & .820 & $15.700^{* *}$ & .738 & \\
\hline \multirow{4}{*}{ Ambient Factor } & AF 1 & .889 & $15.307^{* *}$ & .777 & \multirow{4}{*}{.681} \\
\hline & AF 2 & .809 & --- & .798 & \\
\hline & AF 3 & .806 & $17.300^{* *}$ & .678 & \\
\hline & AF 4 & .678 & $11.313^{* *}$ & .654 & \\
\hline \multirow{4}{*}{ Design Factor } & DF 1 & .668 & --- & .677 & \multirow{4}{*}{.698} \\
\hline & DF 2 & .699 & $17.334^{* *}$ & .546 & \\
\hline & DF 3 & .798 & $12.307^{* *}$ & .579 & \\
\hline & DF 4 & .889 & $13.075^{* *}$ & .789 & \\
\hline \multirow{4}{*}{ Social Factor } & SF 1 & .800 & $10.709^{* *}$ & .700 & \multirow{4}{*}{.592} \\
\hline & SF 2 & .867 & --- & .768 & \\
\hline & SF 3 & .756 & $11.311^{* *}$ & .778 & \\
\hline & SF 4 & .667 & $15.032^{* *}$ & .578 & \\
\hline \multirow{3}{*}{$\begin{array}{l}\text { Hospital } \\
\text { Image }\end{array}$} & HI 1 & .567 & $15.112^{* *}$ & .690 & \multirow{3}{*}{.779} \\
\hline & HI 2 & .557 & $17.732^{* *}$ & .508 & \\
\hline & HI 3 & .678 & --- & .589 & \\
\hline \multirow{3}{*}{$\begin{array}{l}\text { Revisit } \\
\text { Intention }\end{array}$} & RI 1 & .889 & $11.355^{* *}$ & .788 & \multirow{3}{*}{.652} \\
\hline & RI 2 & .867 & $17.001^{* *}$ & .689 & \\
\hline & RI 3 & .788 & --- & .765 & \\
\hline
\end{tabular}

$\chi 2=372.699(\mathrm{df}=179, \mathrm{p}=.000), \mathrm{CMIN} / \mathrm{DF}=2.082, \mathrm{GFI}=.900, \mathrm{AGFI}=.875, \mathrm{NFI}=.905, \mathrm{CFI}=.904,{ }^{* *}: \mathrm{P}<.01$

Construct reliability: Information Quality 0.879 , Service Quality 0.899 , System and Design Quality 0.907, Ambient factor 0.912, Design factor 0.883, Social Factor 0.903, Hospital Image 0.892, Revisit Intention 0.903

Table3 Correlation Matrix

\begin{tabular}{l|l|l|l|l|l|l|l|l}
\hline & \multicolumn{1}{|c|}{ A } & B & C & D & E & F & G & H \\
\hline $\begin{array}{l}\text { Information } \\
\text { Quality: A }\end{array}$ & .746 & & & & & & & \\
\hline $\begin{array}{l}\text { Service } \\
\text { Quality: B }\end{array}$ & .592 & .828 & & & & & & \\
\hline System & .225 & .521 & .768 & & & & & \\
\hline
\end{tabular}




\begin{tabular}{l|l|l|l|l|l|l|l|l}
\hline $\begin{array}{l}\text { \&Design } \\
\text { Quality: C }\end{array}$ & & & & & & & & \\
\hline $\begin{array}{l}\text { Ambient } \\
\text { factor: D }\end{array}$ & .217 & .272 & .441 &. $\mathbf{8 2 5}$ & & & & \\
\hline $\begin{array}{l}\text { Design } \\
\text { factor: } \mathrm{E}\end{array}$ & .279 & .216 & .287 & 237 &. $\mathbf{8 3 5}$ & & & \\
\hline $\begin{array}{l}\text { Social } \\
\text { Factor: F }\end{array}$ & .125 & .141 & .254 & .221 & .223 &. $\mathbf{7 6 9}$ & & \\
\hline $\begin{array}{l}\text { Hospital } \\
\text { Image: G }\end{array}$ & .233 & .300 & .379 & .211 & .410 & .504 &. $\mathbf{8 8 2}$ & \\
\hline $\begin{array}{l}\text { Revisit } \\
\text { Intention: }\end{array}$ & .341 & .352 & .460 & .422 & .407 & .442 & .233 &. $\mathbf{8 0 7}$ \\
\hline
\end{tabular}

\subsection{Test of the structural model}

As the indicator of goodness-of-fit for a structural equation model, $\chi 2$ value is first considered. But, other goodness-of-fit indices like GFI, AGFI, NFI, RMR, and CFI are also considered. The lower $\chi 2$ value is ( $p>0.05$ ), the better the model is. GFI value is from 0 to 1 , and, if GFI value is over .9 when the sample size is 200 , the model is evaluated as a very good one. If AGFI, NFI, CFI, TLI values are $.8 \sim .9$ or over, goodnessof-fit of the model is considered as good. While there are no absolute criteria for RMR value, when the model is good, the value is close to 0 . In general, RMR value ranges on $0.05-0.08$, the model is evaluated as a good one[18].

Before testing the hypotheses of this study, this study tested the goodness-of-fit of the structural equation model. The results are as follows: $\chi 2$ value $=258.192(\mathrm{p}=.000), \mathrm{GFI}=.864, \mathrm{AGFI}=.835, \mathrm{CFI}=.889$, $\mathrm{NFI}=.899, \mathrm{RMR}=.045$, and RMSEA $=.088$. The results did not satisfy the requirements. Therefore, this study improved goodness-of-fit of the model by setting covariance based on modification indices. Indicators of goodness-of fit of the model after modification were as follows: $\chi 2=245.066(p=.000)$. In general, $\chi 2$ is affected by the size of the sample, and, if CMIN/DF is 3.0 or lower, the model is evaluated as being fit. If other indicators also satisfy the criteria of goodness-of-fit, the model is good. In the revised model, CMIN/DF $=2.446$, smaller than 3.0, and GFI=.901, AGFI=.887, CFI=.904 and NFI=.909, which proves that the model is good for testing hypotheses.

Through path analyses of the final structural equation model, H1 (Hospital mobile website quality will have positive effect on hospital image) was tested. The analysis showed that among the kinds of website quality, information quality had the greatest effect on hospital image $(\beta=.629, P=.000)$. So, H1-1 was adopted. It was found that service quality did not affect hospital image. So, H1-2 was rejected. Finally, among the kinds of website quality, system and design had effect on hospital image $(\beta=.501, P=.000)$. So, H1-3 was adopted. Thus, the proportion of effects among the kinds of website quality on hospital image, information quality was the biggest, followed by system and design.

Next, H2 (Service scape will have positive effect on hospital image) was tested. Among the kinds of service scape, ambient condition was found not to have effect on hospital image $(\beta=.061, P=.320)$. So, H21 was rejected. Design factor was found to have significant effect on hospital image $(\beta=.412, P=.000)$. So, $\mathrm{H} 2-2$ was adopted. Finally, social factor also had significant effect on hospital image $(\beta=.248, \mathrm{P}=.000)$. So, $\mathrm{H} 2-3$ was adopted. The order of proportions of effect of hospital service scape on hospital image was as follows: design factor, social factor, and ambient condition in descending order. The effect of hospital image on revisit intention was $\beta=.513(\mathrm{P}=.000)$. So, $\mathrm{H} 3$ was adopted. Therefore, the hypotheses of this study were adopted at .05 level, except for H1-2 and H2-1.

Table4 Structure model path analysis

\begin{tabular}{l|l|l|l|l|l}
\hline H & Path & Estimate & S.E & C.R & $\begin{array}{l}\mathbf{p} \\
\text { value }\end{array}$ \\
\hline $1-1$ & $\begin{array}{l}\text { Information Quality } \\
--->\text { Hospital Image }\end{array}$ & .629 & 0.061 & $9.714^{* *}$ & .000 \\
\hline
\end{tabular}




\begin{tabular}{l|l|l|l|l|l}
\hline $1-2$ & $\begin{array}{l}\text { Service Quality } \\
--->\quad \text { Hospital Image }\end{array}$ & -.055 & .035 & -1.627 & .103 \\
\hline $1-3$ & $\begin{array}{l}\text { System and Design Quality } \\
--->\quad \text { Hospital Image }\end{array}$ & .501 & .073 & $6.863^{* *}$ & .000 \\
\hline $2-1$ & $\begin{array}{l}\text { Ambient Factor } \\
--->\text { Hospital Image }\end{array}$ & .061 & .117 & 0.522 & .320 \\
\hline $2-2$ & $\begin{array}{l}\text { Design Factor } \\
--->\quad \text { Hospital Image }\end{array}$ & .412 & .071 & $5.779^{* *}$ & .000 \\
\hline $2-3$ & $\begin{array}{l}\text { Social Factor } \\
--->\quad \text { Hospital Image }\end{array}$ & .248 & .051 & $4.462^{* *}$ & .000 \\
\hline 3 & $\begin{array}{l}\text { Hospital Image } \\
--->\text { Revisit Intention }\end{array}$ & .513 & .153 & $3.228^{* *}$ & .000 \\
\hline
\end{tabular}

$* *:=t$-statistic $(\geqq 1.96)$ sig. level of $\mathrm{p}<0.05$

\section{Conclusion}

Recently, as medical tourism is viewed as a high value-added industry, many countries make efforts to attract medical tourists by linking medical tourism with other tourist attractions of their countries. In particular, Chinese medical tourists to Korea will continue to be an important group of customers in the medical tourism industry of Korea. Accordingly, this study tried to examine the effect of hospital mobile website quality, service scape of Korean hospitals on hospital image and revisit intention. The findings of the analysis would give practical hints to raise satisfaction of such medical tourists, and be used as important data to attract medical tourists. Through theoretical discussions, this study divided hospital mobile website quality into information quality, service quality, and system and design quality. It also classified service scape into ambient factor, design factor, and social factor. This study conducted a survey to Chinese medical tourists visiting hospitals in Gangnam, Seoul. The conclusion about the findings and suggestions are as follows.

First, H1 (Hospital mobile website quality will have positive effect on hospital image) was partially adopted. Specifically, it was found that, among the kinds of hospital website quality, information quality (H1-1) and system design quality (H1-3) have significant positive effects on hospital image. That is, the more tourists positively perceive information on the hospital, on the medical team of the hospital, on surgery process, and on the effects of surgery, the higher their image of the hospital gets. And the more they perceive the type style, colors, layout, and buttons of the website as convenient and useful, the higher their image of the hospital gets.

Meanwhile, among the kinds of mobile website quality, reservation and tourism service were found not to affect hospital image. We can figure out that Chinese medical tourists form hospital images through various kinds of information provided by hospitals. Specialties of hospital and medical doctors, treatment schedules, and allotment of professional nurses work as important elements for such tourists to get the hospital image. Consequently, it is important to construct the mobile website by properly displaying specialized treatments and specialties of the medical team in reader-friendly methods.

Second, H2 (Service scape will have positive effect on hospital image) was partially adopted. Among ambient factor, design factor, and social factor of hospital service scape, design factor and social factor were found to significantly affect hospital image. Ambient factor such as temperature, humidity, air, and lighting did not affect the hospital image (H2-1). That is, the more tourists positively perceive design factor such as facility interior design, layout, and convenience facilities, the more they tend to have good image of the hospital. The social factor such as clothes of employees, hospitality, the number of the medical team, and waiting lists affect the hospital image. The higher they perceive the social factor, the higher their hospital image gets.

On the contrary, they do not put much importance on ambient elements such as temperature, humidity, air, and lighting. In summary, among the three factors composing the service scape of a medical center, what affects the most significantly is design factor, followed by social factor, evidencing the importance of the physical environment of hospital. In the situation where competition among the advanced countries in medical tourism and late comers gets tough, hospital managers should be aware of the importance of 
service scape. Third, it was found that hospital image has positive effect on revisit intention, and willingness to encourage the hospital to others among medical tourists.

Based on the findings of the analysis, this study wants to suggest the following hints to those related with the medical tourism industry. First, as hospital information has positive effect on hospital image, it is desirable for such hospitals to introduce detailed information on the specialized treatments and clinical experiences on its website. The fact that information not only on medical doctors, but also on nurses has positive effect on hospital image, it is possible that specialties of hospital employees at various encounters should be emphasized as well.

Second, unlike the case of PC, small mobile website screen is limited in containing various kinds of information. Considering such a limitation of mobile device, website designers should be careful of harmony of colors and layout composition in order to make users easily get wanted information. And on medical information common people cannot easily understand, it is necessary for website designer to not only give written information, but use drawings and illustrations or show the information using graph or figures.

Third, to raise hospital image Chinese medical tourists perceive and encourage them to revisit, service scape is as much important as medical service. To excel in the tough competition to attract medical tourists, Korea and Korean hospitals should make efforts to make not only medical service but physical and social environment such as service scape of hospitals competitive.

Given the situation where there are not enough researches on hospital mobile website quality and service scape, this study can be very meaningful. However, it has some limits in the sense that it only deals with Chinese medical tourists. In the future studies, it is necessary to include medical tourists from different countries that have different Internet environments and cultures. In the future studies, it is desirable to do wider and continuous researches applying demands of medical tourists visiting Korea.

\section{References}

[1] Shabir S, Sharma R. Role of Soft Skills in Tourism Industry in Saudi Arabia. International Journal of Engineering and Management Research. 2019;9(4):88-92. DOI: https://doi.org/10.31033/ijemr.9.4.14

[2] Hunter-Jones P. Cancer and tourism. Annals of Tourism Research. 2005;32(1):70-92. http://www.riss.kr/link?id=042089337

[3] https://www.koreahealthtour.co.kr/kima/medical-treatment-in-korea/ 2020

[4] Matura P. Digital Marketing Mix Strategies in the Tourism Industry in Zimbabwe: A Masvingo Tourism Destination Perspective. International Journal of Engineering and Management Research. 2018;8(6):211219. DOI: $10.31033 /$ ijemr.8.6.22

[5] Wen C, Prybutok VR, Blankson C, Fang J. The role of E-quality within the consumer decision making process. International Journal of Operations \& Production Management. 2014; 34(12):1506-1536. DOI: 10.1108/IJOPM-07-2013-0352

[6] Santos J. E-service quality, a model of virtual service quality dimensions. Managing Service Quality. 2003;13(3):233-246. DOI: 10.1108/09604520310476490

[7] Poddar A, Donthu N, Wei Y. Website customer orientation, website quality, and purchase intention, The role of website personality. Journal of Business Research. 2008;62(4):441-450. DOI: 10.1016/j.jbusres.2008.01.036

[8] Kim J, Lennon SJ. Effects of reputation and website quality on online consumers' emotion, perceived risk and purchase intention. Journal of Research in Interactive Marketing. 2013;7(1): 33-56. DOI: 10.1108/17505931311316734

[9] Parasuraman A, Zeithaml VA, Berry LL. A Conceptual Model of Service Quality and Its Implications for Future Research. American Marketing Association. 1985;49(4):41-50. DOI: 10.2307/1251430

[10] Baker J, Grewal D, Parasuraman A. The influence of store environment on quality inferences and store image. Journal of the Academy of Marketing Science. 1994;22(4):328-339. DOI: 10.1177/0092070394224002

[11] Bitner MJ. Servicescapes: The impact of physical surroundings on customers and employees. American Marketing Association 1992;56(2):57-71. DOI: $\quad$ 10.2307/1252042

[12] Baker J, Parasuraman A, Grewal D, Voss G. The Influence of Multiple Store Environmental Cues on Perceived Merchandise Value and Patronage Intentions. American Marketing Association. 2002 Apr;66(2):120-141. DOI: $\quad$ 10.1509/jmkg.66.2.120.18470

[13] Hightower R, Shariat M. Servicescapes Hierarchical Factor Structure Model. Global Review of Business and Economic Research Journal. 2009;5(2):375-398.

[14] Wakefield KL, Blodgett JG. The effect of servicescape on customers' behavioral intentions in leisure 
service settings. Journal of Services Marketing. 1996;10(6):45-61. DOI: $\quad$ 10.1108/08876049610148594 [15] Lin IY, Worthley R. Servicescape moderation on personality traits, emotions, satisfaction, and behaviors. International Journal of Hospitality Management. 2011;31(1):31-42. DOI: 10.1016/j.ijhm.2011.05.009

[16] Hightower R. Conceptualizing and Measuring Servicescape's Impact on Service Encounter Outcomes. Unpublished Doctoral Dissertation, Florida State University, Tallahassee, FL, U. S; 1997

[17] Harris L, Ezeh C. Servicescape and Loyalty Intention: An Empirical Investigation. European Journal of Marketing. 2008;42(3):390-422. DOI: 10.1108/03090560810852995

[18] Anderson JC, Gerbing DW. Structural equation modeling in practice: A review and recommended two-step approach. Psychological Bulletin. 1988;103(3):411-423. DOI:10.1037/0033-2909.103.3.411

[19] Fornell C, Larcker DF. Evaluating structural equation models with unobservable variables and measurement error. Journal of Marketing Research. 1981;18(1):39-50. . DOI:10.2307/3151312

[20] Bhoi, A. K., Sherpa, K. S., \& Khandelwal, B. (2018). Arrhythmia and ischemia classification and clustering using QRS-ST-T (QT) analysis of electrocardiogram. Cluster Computing, 21(1), 1033-1044.

[21] Reddy, A. V., Krishna, C. P., \& Mallick, P. K. (2019). An image classification framework exploring the capabilities of extreme learning machines and artificial bee colony. Neural Computing and Applications, 121.

[22] Bisoy, S. K., Mallick, P. K., \& Mishra, A. Fairness Analysis of TCP Variants in Asymmetric Network. International Journal of Engineering \& Technology, 7(2.12), 231-233.

[23] Mallick, P. K., Mishra, D., Patnaik, S., \& Shaw, K. (2016). A semi-supervised rough set and random forest approach for pattern classification of gene expression data. International Journal of Reasoningbased Intelligent Systems, 8(3-4), 155-167.

[24] Mallick, P. K., Mohanty, B. P., \& Jha, S. A novel approach using. Supervised and Unsupervised Learning" to prevent the adequacy of Intrusion Detection Systems", International Journal of Engineering \& Technology, 7(3.34), 474-479.

[25] Satapathy, S. K., Mishra, S., Sundeep, R. S., Teja, U. S. R., Mallick, P. K., Shruti, M., \& Shravya, K. (2019). Deep learning based image recognition for vehicle number information. International Journal of Innovative Technology and Exploring Engineering, 8, 52-55.

[26] Mallick, P. K., Kar, S. K., Mohanty, M. N., \& Kumar, S. S. (2015). Use of histogram approach in color band detection for electrical passive component. International Journal of Applied Engineering Research, 10(44), 31446-31450.

[27] Mishra, S., Mallick, P. K., Tripathy, H. K., Bhoi, A. K., \& González-Briones, A. (2020). Performance Evaluation of a Proposed Machine Learning Model for Chronic Disease Datasets Using an Integrated Attribute Evaluator and an Improved Decision Tree Classifier. Applied Sciences, 10(22), 8137.

[28] Bhoi, A. K., Sherpa, K. S., \& Mallick, P. K. (2014, April). A comparative analysis of neuropathic and healthy EMG signal using PSD. In 2014 International Conference on Communication and Signal Processing (pp. 1375-1379). IEEE.

[29] Bhoi, A. K., Sherpa, K. S., Khandelwal, B., \& Mallick, P. K. (2019). T Wave Analysis: Potential Marker of Arrhythmia and Ischemia Detection-A Review. In Cognitive Informatics and Soft Computing (pp. 121-130). Springer, Singapore.

[30] Mishra, S., Mallick, P. K., Jena, L., \& Chae, G. S. (2020). Optimization of Skewed Data Using SamplingBased Preprocessing Approach. Frontiers in Public Health, 8.

[31] Bhoi, A. K., \& Sherpa, K. S. (2016). Statistical analysis of QRS-complex to evaluate the QR versus RS interval alteration during ischemia. Journal of Medical Imaging and Health Informatics, 6(1), 210-214.

[32] Mishra, S., Tripathy, H. K., Mallick, P. K., Bhoi, A. K., \& Barsocchi, P. (2020). EAGA-MLP-An Enhanced and Adaptive Hybrid Classification Model for Diabetes Diagnosis. Sensors, 20(14), 4036.

[33] Bhoi, A. K., Mallick, P. K., Liu, C. M., \& Balas, V. E (Eds.) (2021). Bio-inspired Neurocomputing, Springer. [34] Oniani, S., Marques, G., Barnovi, S., Pires, I. M., \& Bhoi, A. K. (2020). Artificial Intelligence for Internet of Things and Enhanced Medical Systems. In Bio-inspired Neurocomputing (pp. 43-59). Springer, Singapore.

[35] Marques, G., Bhoi, A.K., Albuquerque, V.H.C. de, K.S., H. (Eds.) (2021). IoT in Healthcare and Ambient Assisted Living, Springer

[36] Marques, G., Miranda, N., Kumar Bhoi, A., Garcia-Zapirain, B., Hamrioui, S., \& de la Torre Díez, I. (2020). Internet of Things and Enhanced Living Environments: Measuring and Mapping Air Quality Using Cyber-physical Systems and Mobile Computing Technologies. Sensors, 20(3), 720. 